by the reduction of a basic symbol to bare essentials or by an almost fresh nuance. The overt epilogue, serene or agonized, is the commonest type of fulfilment of this kind, but the magnificently pioneering finale of $A$ Sea Symphony created a precedent of unpredictably late 'sailing forth.' It recurred in principle, still somewhat bafflingly for one listener, in Sancta Civitas and in the startling coda of the scherzo of the Pastoral Symphony, inexorably pursued in No. 4 with a fresh movement as coda, and in No. 6 with a continuing finale to end all funales. More genial instances appear in the short but substantial Benedicite (for Leith Hill) and Thanksgiving for Victory, a fine sublimation of the conflicting emotions of I 945, too datable, alas! for public revival.

A school photograph, as described to me some years ago, shewed Vaughan Williams "very much as he is now . . . looking out into the distance . . . a master of the event". That, too, is the growing impression of his music, advancing, sooner or later, toward the unknown region already perceived and leaving it with enhanced stature. We shall not forget these strivings, and the best of him remains ours to conserve, in parish building and city hall, and in many faithful recordings, glorifying the creation of man.

\section{A. E. F. Dickinson}

\section{ER W IN STEIN \\ $1885-195^{8}$}

Last July, a young musician said to me that Erwin Stein's death had deprived this country of the sort of musical influence we could least do without-someone with the whole of European culture behind him who yet lived and thought in the present and was able and prepared to impart this wisdom without preaching.

Erwin Stein was born in Vienna in 1885 . His education was at the Franz Josephs Gymnasium and the University of Viennaand, he would have added, at Mahler's operatic and concert performances. His father was a book publisher who specialized in law books, and Erwin, as the youngest of a family which included painters and amateur musicians, moved in an artistic atmosphere from childhood. Mahler was his ideal, and he could describe in detail what Mahler did at this or that point in fifty different scores, how-in the shaping of the phrases, not only the giving of extra confidence-he could raise the standard of the singers who sang with him, what happened at the first Viennese performances of Mahler's own music which was to Erwin a revelation, to his compatriots an occasion for acrimony. He started to study with Schoenberg in 1906, and in a sense this was a process which never stopped till the end of his life. In 1910 he embarked on the career of a professional musician, and during the next years he was coach and conductor at various opera houses, in Aussig, Strasbourg, Danzig, Osnabrück, Flensburg and Darmstadt. I think Darmstadt was his happiest memory of these years, partly because there he heard and met Nikisch, there Kleiber was a colleague, there was some approximation in the modern world to the Greek ideal of the enlightened city, there above everything he met his wife. Kleiber remained a friend of his, and whenever he came to London, they met and discussed Darmstadt and Vienna, Mahler and Wozzeck and Schoenberg-and Kleiber as often as not had to take advantage of the fact that only from Erwin could he borrow a shirt which would not look like a bell-tent on him.

Erwin was never strong and he eventually decided that the gruelling life of a conductor in the theatre was not for him. He returned to Vienna in 1919, and for two years helped Schoenberg run an association for the private performance of new music, particularly by Schoenberg and his pupils. During this period he prepared and conducted a performance of Schoenberg's Picrrot lunaire with Erika Wagner (later, wife of Fritz Stiedry) as soloist; it was looked upon as a model of its kind, and with Schoenberg's encouragement it toured all over Europe, even penetrating as far as London. From 1924 to 1938 he worked as artistic adviser to Universal Edition in Vienna, and during this time he was in contact with almost every contemporary musician who came within the Austro-German orbit. For UE he made many vocal scores and, to make the music more generally accessible, orchestral reductions of some movements of Mahler symphonies and of Schoenberg's Gurrelieder, the latter of which was heard at the Edinburgh Festival a few years ago. From 1924 to 1930 he edited $P u l t$ und Taktstock, a magazine for conductors, and for some time he was correspondent in Vienna for the Boston Christian Science Monitor, an activity he continued in London till the day of his death. From 1929 to 1934 he was chorus master of the Typographia Choir, and with them he conducted music such as Beethoven's Ninth Symphony, Mahler's Second, Das lied von der Erde, Schoenberg's Friede auf Erden. I shall not forget the mixture of amusement, pride and emotion with which he reacted to an old member of his choir who came up to him in 1950, when he and I were walking in the Mirabell Gardens in 
Salzburg, and greeted him as "Herr Chormeister!" In Vienna, he was active as conductor and teacher, he lectured and he wrote quantities of articles, often with the object of making more accessible the music of Schoenberg's circle. His friends were Schoenberg and Kolisch, Jalowetz and Steuermann, Webern and Alban Berg-above all perhaps the genial and lovable Berg, for whom he had a particular affection. By the time he left Vienna he had known them as colleagues and friends for over thirty years. He always told me he had no time for the English viewsentimental he thought it, and unrealisticwhich envied the scandals at Schoenberg premières as evidence of the violence of Viennese musical feeling; far better the gentler, if perhaps no less bewildered, English reaction, which at least had the advantage of good manners! Yet, after Weingartner had succeeded Mahler at the Vienna Opera, he himself joined with Webern and other members of Schoenberg's group in vigorous vocal protest against the new Director's cuts in Die Walküre, and spent the night in the $e^{t}$ city jail for his artistic integrity. Berg, he said, was sitting with a wealthy friend in a box, and did not feel he could in splendid isolation contribute to the din which came from the gallery.

In 1938 the advent of Hitler forced him to leave Vienna, and he joined Boosey and Hawkes, who were at that time affiliated with Universal Edition. Here his work soon brought him into contact with English musicians, and in particular with Benjamin Britten. He made no secret of what music he liked; on the contrary he put his considerable energies into doing whatever he could to make it better understood, and the friendship between him and Britten grew very rapidly (The Rape of Lucretia is dedicated to him). Apart from his work as publisher, life in England consisted of the same sort of activities as had life in Vienna-writing, occasional lecturing, teaching, and continual talk about music. For a time he edited Tempo and he played a prominent part in organizing the valuable series of chamber concerts late in the war which were run by Boosey and Hawkes; his own contribution was a notable performance of Pierrot lunaire. He published a book of collected writings, Orpheus in new guises, edited Schoenberg's Letters (about to be published in Germany), and for years had been engaged on an important book on the subject of musical performance.

Erwin Stein's range of musical interest was wide, but he would have scorned to have made out that it included everything in any style.
Nobody in my experience was better able to concentrate on the musical wood undisturbed by the trees, and it was this concentration on essentials that made him so constructive a teacher. I think in a way this word ' constructive' describes him better than any. He wanted to learn for the future from everything he met. He was incapable of applying his store of knowledge in any other way, and this was as true of him in a committee room or as a writer as it was of him as a musician. His enthusiasm for Schoenberg as influence, teacher and above all composer could never lead him to denigrate other schools of thought simply because they were different-as witness his love of Mahler and his championing of Britten and the music of his own pupils. His exact knowledge of a great range of the finest performances spread over more than fifty years of adult life never induced him to judge what he heard by the standards of reminiscence - surely an infallible sign of growing old; it was what the music needed that mattered to him and nothing else. If he discerned the seeds of musical understanding, if the general trend was musical and there was a regard for shape, a performer would earn his approbation and anyone who consulted him was sure of a meticulous analysis of his virtues as well as of his faults, of a stimulating view of the work in question, of encouragement for his future performance of it. That his mind was analytical goes without saying, but that is by no means to infer that his reaction to what he heard was cool. He remained an enthusiast and a learner to the last days of his life, and his joy in the performance that had fully met the requirements of the music-he would have loathed the phrase 'met his standards'warmed everyone who had participated. "Why can't conductors understand that a hurried fast tempo sounds less brilliant than a slower one better articulated?" . . . "When they have a sustained note, singers so seldom convey from the outset the exact length and weight of the note" ...

None of us who have known and loved him and shared in his more recent musical experiences-I say ' shared ' because he loved to spread his enthusiasm and to discuss what one had been listening to, regardless of the musical standing of his friends-can but miss him. There was no problem for which he would not offer his help in the search for a solution, none on which his advice was not solid as well as stimulating and wise; there was no experience, musical or otherwise, which was not the greater and the richer for being shared with him.

HarewoOd 